\title{
Study of Serum Golgi Protein 73 Level as a Marker for Diagnosis of Hepatocellular Carcinoma
}

\author{
Hany Said Sabry ${ }^{1}$, Hossam Ibrahim Mohamed ${ }^{1}$, \\ Wafaa Mahmoud Radwan ${ }^{2}$, Naglaa Said Mohamed El-Abd ${ }^{1}$ \\ ${ }^{I}$ Tropical Medicine Department, Faculty of Medicine, Menoufia University, Menoufia, Egypt \\ ${ }^{2}$ Clinical Pathology Department, Faculty of Medicine, Menoufia University, Menoufia, Egypt
}

Corresponding Author Naglaa Said Mohamed El-Abd

Mobile:

$+201092304322$

E mail:

Naglaa_elabd@yahoo. com

Key words: Golgi protein 73, Hepatocellular carcinoma, Alphafetoprotein
Background and study aim:Hepatocellular carcinoma (HCC) is the fifth most common neoplasm in the world, and the third most common cause of cancerrelated death. Golgi protein 73 is normally expressed in epithelial cells of many human tissues. GP73 expression is upregulated in hepatocytes, and in serum from patients with hepatitis and liver cirrhosis regardless the etiology. This work aimed to study the diagnostic role of serum Golgi protein 73level as a marker for HCC.

Patients and methods:This study was conducted on 48 patients with HCC on top of liver cirrhosis (GI), 20 patients with liver cirrhosis (GII), and 20 healthy controls (GIII). Patient and controls were subjected to careful medical history, full clinical examination and laboratory investigations including CBC, ESR, liver function tests, renal function tests, viral markers, serum AFP and Serum Golgi protein 73 by ELISA.

\section{INTRODUCTION}

Hepatocellular carcinoma (HCC) is the fifth most common neoplasm in theworld, and the third most common cause of cancer-related death. The burden of this devastating cancer is expected to increase further in coming years [1].As most patients with HCC are diagnosed at an advanced stage with underlying liver dysfunction, the mortality rate of $\mathrm{HCC}$ is similar to the incidence rate. Early detection of $\mathrm{HCC}$ is therefore extremely important in improving the survival of patients [2].

Approximately $70 \%-90 \%$ of patients with HCC have an established background of chronic liver disease and cirrhosis, with major risk factors for
Results:Serum GP73 showed highly significant increase (with $\mathrm{P}$ value $<0.001$ ) in $\mathrm{HCC}$ group $\mathrm{X} \pm \mathrm{SD}(1765.92 \pm 747.99)$ in comparison with cirrhotic $\mathrm{X} \pm \mathrm{SD}$ $(772.45 \pm 73.84)$ and control $\mathrm{X} \pm \mathrm{SD}$ (458.30 \pm 103.03$)$ groups, also significantly increased in cirrhotic group in comparison with control group. There was significant increase in mean values of serum GP73 in patients with HCC associated with portal vein thrombosis or lymph node enlargement also there was significant positive correlationbetween GP73 and tumor size. In diagnosis of $\mathrm{HCC}$, at cut off point $55 \mathrm{ng} / \mathrm{ml}$, AFP had sensitivity $81.3 \%$ and specificity $70.0 \%$, and $\mathrm{Gp} 73$ at cut off point $847.5 \mathrm{ng} / \mathrm{l}$, the sensitivity was $93.8 \%$ and specificity $90.0 \%$. With combined use of AFP and Gp73: the sensitivity of diagnosis of HCC increased to $95.8 \%$.

Conclusion:Significant increase in sensitivity, accuracy and negative predictive value with combined use of AFP and Gp73 than AFP alone in diagnosis of HCC.

developing cirrhosis including chronic infection with hepatitis $\mathrm{B}$ virus (HBV),hepatitis C virus (HCV), alcoholic liverdisease, and nonalcoholic steatohepatitis(NASH). Patients with cirrhosis are thus usually included in surveillance plans [3].

AFP is the most widely tested biomarker in HCC. But the clinical value of AFP is challenged due to low sensitivity and specificity. AFP is not elevated in all patients with HCC. Some patients with cirrhosis and/or hepatic inflammation can have an elevated AFP, even withoutthe presence of a tumor [4]. Alternative serum biomarkers are being actively sought include prothrombin induced byvitamin $\mathrm{K}$ absence (PIVKA), glypican-3, 
and squamous cell carcinoma antigen-1; however, none of these have been adequately investigated to be recommended as a screening test [5].

Golgi protein 73 (GP73) also named Golgi phosphorprotein 2 (GOLPH2), is a type II Golgi localized integral membrane protein that is normallyexpressed in epithelial cells of many human tissues. GP73 was first identified in a genetic screen for proteins with differential expression in adult giant-cell hepatitis (GCH) [6]. It is consistently present in biliary epithelial cells in normal livers, and hepatocytes show little or no signal. However, GP73 expression is upregulated in hepatocytes, and in serum samples from patients with acute \& chronic hepatitis and liver cirrhosis regardless the etiology [7]. The aim of the present work was to study the diagnostic role of serum Golgi protein 73level as a marker for HCC in comparison with serum Alpha-fetoprotein.

\section{PATIENTS AND METHODS}

This study was conducted on 68 patients with liver cirrhosis with or without HCC and 20 healthy subjects of matched age and sex as controls. Patients and controls were selected from inpatients and outpatients clinic of TropicalMedicineDepartmentMenoufiaUniversit yHospital in the period between June 2012 and December 2013. Patients were 52 (76.5\%) males and $16(23.5 \%)$ females. Their ages were ranging between 31-76 years old. An informed consent was obtained before patients entered the study. Diagnosis of cirrhosis was done by clinical examination, ultra-sonographic finding and laboratory investigations; while diagnosis of HCC was done by their characteristic features in 2 imaging methods (abdominal ultrasonography and triphasic $\mathrm{CT}$ ).

\section{Patients and controls were classified into the following groups:}

Group I: Comprised 48 patients with HCC on top of liver cirrhosis. All patients did not receive prior treatment for HCC.

Group II: Comprised 20 patients with liver cirrhosis.

Group III: Comprised 20 healthy subjects as a control group.

\section{Exclusion criteria:}

1. Focal hepatic lesions other than HCC (cholangiocarcinoma, hemangioma, hepatoblastoma, metastatic focal lesions...etc).

2. Malignancy elsewhere
Patients and controls were subjected to the following:

1- Careful medical history

2- Full clinical examination

3- Laboratory investigations including complete blood picture, ESR, liver function tests, renalfunction tests and viral markers

4- Serum AFP level by ELISA

5- Serum Golgi protein 73 was quantitatively determined by ELISA GP73 provided by Glory science catalog number 11598 . The range of the kit was: $50 \mathrm{ng} / \mathrm{L} \rightarrow 1500 \mathrm{ng} / \mathrm{L}$. Principle of test; the kit used a double-antibody sandwich ELISA to assay the level of Human Golgi protein-73(GP-73) in samples. Add (GP-73) to monoclonal antibody Enzyme well which is pre-coated with Human (GP-73)monoclonal antibody, incubation; then, add (GP-73) antibodies labeled with biotin, and combined with Streptavidin-HRP to form immune complex; then carry out incubation and washing again to remove the uncombined enzyme. Then add Chromogen Solution A, B, the color of the liquid changes into the blue, and at the effect of acid, the color finally becomes yellow. The chroma of color of the Human Substance (GP73) of sample was positively correlated.

6- Imaging studies (abdominal ultrasonography, triphasic CT).

\section{Statistical Analysis:}

The data were collected, tabulated, and analyzed by SPSS (statistical package for social science) version 17.0 on IBM compatible computer. Significance of results: Non-significant difference if $\mathrm{P}>0.05$, Significant difference if $\mathrm{P}<0.05$ and highly significant difference if $\mathrm{P}<0.01$.

\section{RESULTS}

\section{Demographics of the studied groups}

There was no significant difference between the three studied groups as regards age and sex.Patients were $52(76.5 \%)$ males and 16 $(23.5 \%)$ females. Their ages were ranging between 31-76 years old as well as 20 healthy subjects of matched age and sex as controls. Themean of age in HCC group was 57.85 \pm 7.23 , in cirrhotic group was $48.25 \pm 7.99$ and in control group was $54.70 \pm 8.12$. In GI, there were 38 (79.2\%) males and $10(20.8 \%)$ females, in GII there were $14(70 \%)$ males, and $6(30 \%)$ females and in GIII there were14 (70\%) males, and 6 $(30 \%)$ females.Manifestations of cirrhosis were 
present in various proportions in all GI and GII patients. Some manifestations consistent with HCC (anorexia and loss of weight) were present in various proportions in HCC patients.

\section{Biochemistry of the studied groups}

There was highly significant decrease in mean values of hemoglobin concentration and platelet count in HCC and cirrhotic groups in comparison with control group. While there was no significant difference between GI \& GII as regards platelets count and $\mathrm{Hb}$ concentration. There was no significant difference between studied groups as regards total WBCs.

Statistical analysis revealed that there was highly significant increase in mean values of AST, ALT and serum bilirubin as well as highly significant decrease in mean values of serum albumin and prothrombin concentration in HCC and cirrhotic groups in comparison with control group.

Chronic HCV was the commonest etiology of cirrhosis in GI (85.4\%) and GII patients (80.0\%) while chronic HBV was far less common etiology. There was non-significant difference between HCC group and cirrhotic group as regards the Child classification.

Triphasic CT revealed evidence of cirrhosis in all GI \& GII patients as well as imaging evidence consistent with HCC in in all GI patients (Table $1)$.

There was highly significant increase in mean values of serum AFP \& GP73 in HCC group in comparison with other groups and in cirrhotic group in comparison with control group (Table 2).

There was no significant difference in mean values of AFP as regard tumor size in the HCC group, While there was statistical significant increase in the mean values of Gp73 with increasing the tumor size (more than $5 \mathrm{~cm}$ ) (Table 3 and Figure 1).

Statistical analysis revealed significant increase in mean values of serum GP73 in patients with HCC complicated by portal vein thrombosis in comparison with patients without portal vein thrombosis, while there was no significant difference between patients with HCC with or without portal vein thrombosis as regards mean values of AFP. Also there was significant increase in mean values of serum GP73 in patients with HCC associated with lymph node enlargement in comparison with patients without, while there was no significant difference between patients with $\mathrm{HCC}$ with or without lymph node enlargement as regards mean values of AFP (Table 4).

Statistical analysis revealed no significant difference in mean values of AFP as regard Child-Pugh grades (A, B, C) in the HCC group, while there was significant increase in the mean values of Gp73 with increasing Child grades in HCC.There was no significant difference in mean values of both AFP and GP73 as regard Child-Pugh grades $(\mathrm{A}, \mathrm{B}, \mathrm{C})$ in the cirrhotic group (Table 5).

Receiver operating characteristic curve (ROC curve) of AFP and GP73 for diagnosis of HCC versus cirrhotic cases showed that the cutoff point was $55 \mathrm{ng} / \mathrm{ml}$ for AFP and $847.5 \mathrm{ng} / \mathrm{l}$ for GP73 (Figure 2).

At cut off point $55 \mathrm{ng} / \mathrm{ml}$, AFP had sensitivity $81.3 \%$, specificity $70.0 \%$, and accuracy $77.9 \%$, while for Gp73 at cut off point $847.5 \mathrm{ng} / \mathrm{l}$, the sensitivity was $93.8 \%$, specificity $90.0 \%$ and accuracy $92.6 \%$ in diagnosis of HCC. With combined use of AFP and Gp73: the sensitivity increased to $95.8 \%$ (Table 6). 
Table (1): Triphasic CT findings among the studied patients

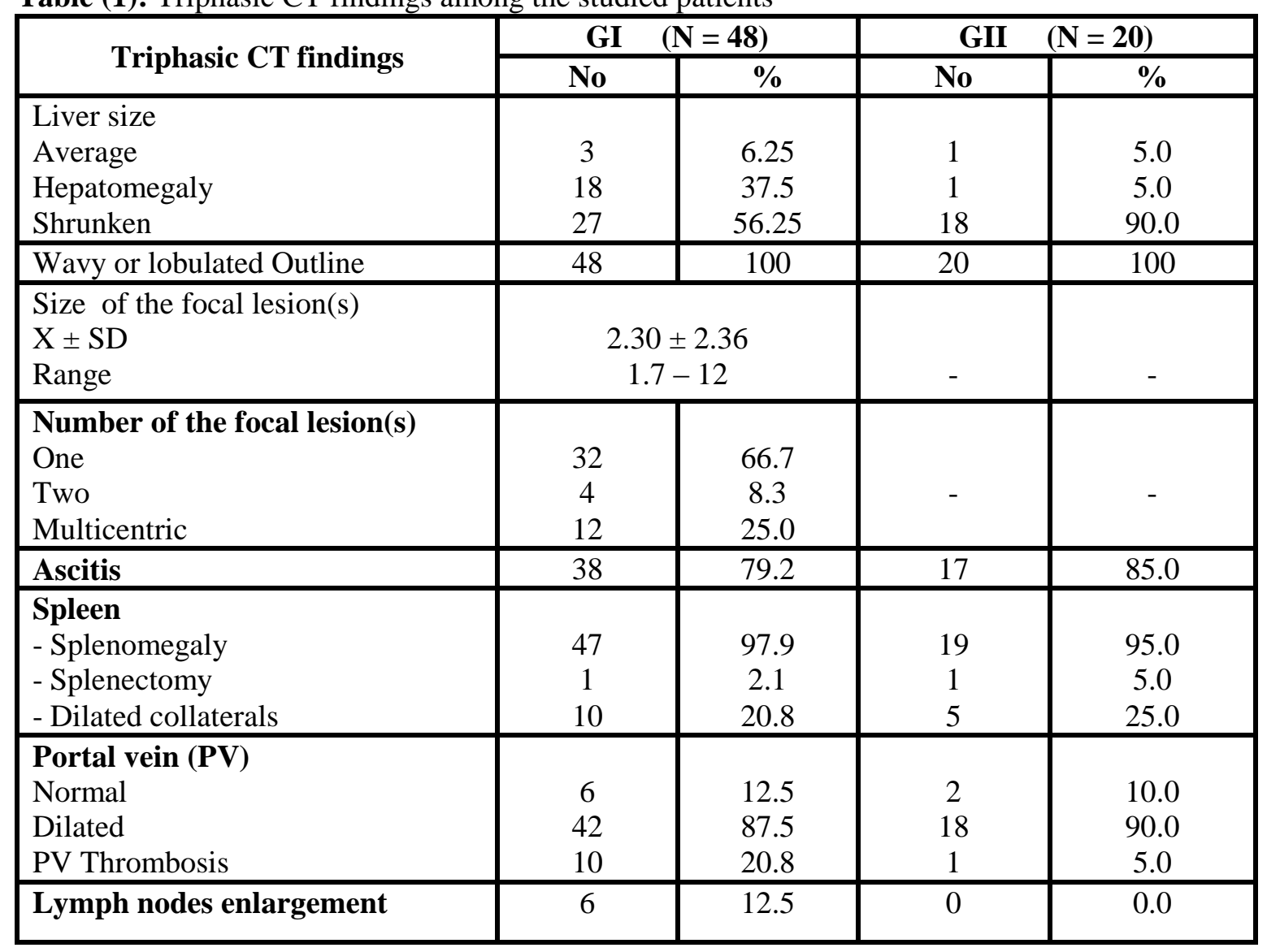

Table (2): Comparison between studied groups as regards AFP and Gp73

\begin{tabular}{|c|c|c|c|c|c|}
\hline & \multicolumn{3}{|c|}{ The studied groups } & \multirow{2}{*}{$\begin{array}{c}\text { Mann } \\
\text { Whitney } \\
\text { U test } \\
\end{array}$} & \multirow[b]{2}{*}{$P$ value } \\
\hline & $\begin{array}{c}\text { Group I } \\
\mathbf{N}=48\end{array}$ & $\begin{array}{c}\text { Group II } \\
\mathbf{N}=\mathbf{2 0}\end{array}$ & $\begin{array}{c}\text { Group III } \\
\mathbf{N}=\mathbf{2 0}\end{array}$ & & \\
\hline $\begin{array}{l}\text { AFP(ng/ml) } \\
X \pm S D \\
\text { Range }\end{array}$ & $\begin{array}{c}771.89 \pm 1002.99 \\
19-2850\end{array}$ & $\begin{array}{c}30.0 \pm 27.17 \\
1-90\end{array}$ & $\begin{array}{c}1.15 \pm 0.94 \\
0.8-5\end{array}$ & $\begin{array}{l}4.86 \\
6.44 \\
5.31\end{array}$ & $\begin{array}{l}<0.001^{1} \\
<0.001^{2} \\
<0.001^{3}\end{array}$ \\
\hline Gp73(ng/l) & & & & & \\
\hline Range & $\begin{array}{c}1765.92 \pm 747.99 \\
810-3515\end{array}$ & $\begin{array}{c}772.45 \pm 73.84 \\
635-890\end{array}$ & $\begin{array}{c}458.30 \pm 103.03 \\
350-665\end{array}$ & $\begin{array}{l}6.23 \\
6.41 \\
4.92\end{array}$ & $\begin{array}{l}<0.001^{1} \\
<0.001^{2} \\
<0.001^{3}\end{array}$ \\
\hline
\end{tabular}

$1=$ Comparison between HCC cases and cirrhotic cases

2 = Comparison between HCC cases and control

$3=$ Comparison between cirrhotic cases and control 
Table (3): The relation between tumor size and AFP \& GP73 levels in GI

\begin{tabular}{|c|c|c|c|c|}
\hline \multirow[b]{2}{*}{ Variable } & \multicolumn{2}{|c|}{ Tumor size } & \multirow{2}{*}{$\begin{array}{c}\text { Kruskal } \\
\text { Wallis Test }\end{array}$} & \multirow[b]{2}{*}{ P value } \\
\hline & $\begin{array}{c}<5 \mathrm{~cm} \\
(\mathrm{n}=26)\end{array}$ & $\begin{array}{l}\geq 5 \mathrm{~cm} \\
(\mathrm{n}=22)\end{array}$ & & \\
\hline $\begin{array}{l}\text { AFP (ng/ml) } \\
\mathrm{X} \pm \text { SD } \\
\text { Range }\end{array}$ & $\begin{array}{c}705.38 \pm 967.58 \\
7-2850\end{array}$ & $\begin{array}{c}850.5 \pm 1060.69 \\
19-2800\end{array}$ & 0.17 & 0.87 \\
\hline $\begin{array}{l}\text { Gp73 (ng/l) } \\
\text { X土SD } \\
\text { Range }\end{array}$ & $\begin{array}{c}1485.85 \pm 575.02 \\
815-2900\end{array}$ & $\begin{array}{c}2106.0 \pm 787.99 \\
895-3515\end{array}$ & 2.76 & 0.006 \\
\hline
\end{tabular}

\section{Correlation between GP73 and tumor size}

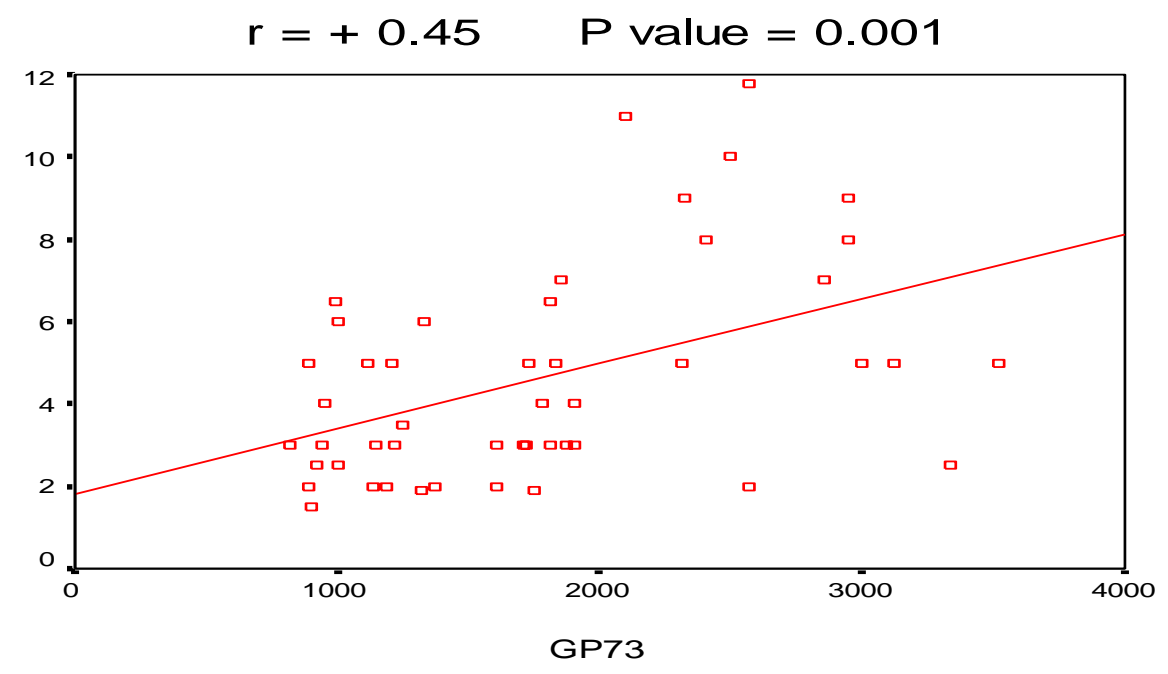

Figure 1 Showed significant positive correlation between GP73 and tumor size

Table (4): The relation between AFP \& GP73 levels and PV thrombosis or LN enlargement in GI

\begin{tabular}{|c|c|c|c|c|}
\hline \multirow{2}{*}{ Variable } & \multicolumn{2}{|c|}{ Portal vein } & \multirow{2}{*}{$\begin{array}{c}\text { Mann } \\
\text { Whitney U }\end{array}$} & \multirow{2}{*}{$P$ value } \\
\hline & Patent(n=38) & Thrombosis $(n=10)$ & & \\
\hline $\begin{array}{l}\text { AFP (ng/ml) } \\
\mathrm{X} \pm \mathrm{SD} \\
\text { Range }\end{array}$ & $\begin{array}{c}743.84 \pm 1014.92 \\
19-2800\end{array}$ & $\begin{array}{c}878.5 \pm 1001.46 \\
10-2850\end{array}$ & 0.56 & 0.58 \\
\hline \multirow[t]{3}{*}{$\begin{array}{l}\text { Gp73 (ng/l) } \\
\text { X } \pm \text { SD } \\
\text { Range } \\
\end{array}$} & $\begin{array}{c}1660.63 \pm 726.35 \\
815-3515\end{array}$ & $\begin{array}{c}2186.0 \pm 681.76 \\
895-2915\end{array}$ & 2.07 & 0.04 \\
\hline & \multicolumn{2}{|c|}{ Lymph nodes enlargement } & & \\
\hline & $\begin{array}{c}\text { LN enlargement } \\
(\mathrm{n}=6)\end{array}$ & $\begin{array}{c}\text { No LN enlargement } \\
(n=42)\end{array}$ & & \\
\hline $\begin{array}{l}\text { AFP (ng/ml) } \\
\mathrm{X} \pm \mathrm{SD} \\
\text { Range }\end{array}$ & $\begin{array}{c}1455.0 \pm 1438.95 \\
49-2850\end{array}$ & $\begin{array}{c}674.31 \pm 907.01 \\
19-2800\end{array}$ & 1.28 & 0.20 \\
\hline $\begin{array}{l}\text { Gp73 (ng/l) } \\
\text { X } \pm \text { SD } \\
\text { Range }\end{array}$ & $\begin{array}{c}2487.67 \pm 455.41 \\
1781-3515\end{array}$ & $\begin{array}{c}1662.81 \pm 727.29 \\
810-2995\end{array}$ & 2.56 & 0.01 \\
\hline
\end{tabular}


Table (5): The relation between Child classification and AFP \& GP73 in GI \& GII

\begin{tabular}{|c|c|c|c|c|c|}
\hline \multirow[b]{2}{*}{ Variable } & \multicolumn{3}{|c|}{ Child-Pugh classification in GI } & \multirow{2}{*}{$\begin{array}{c}\text { Kruskal } \\
\text { Wallis } \\
\text { Test }\end{array}$} & \multirow{2}{*}{$\begin{array}{c}\mathbf{P} \\
\text { value }\end{array}$} \\
\hline & $\begin{array}{c}\mathrm{A} \\
(\mathrm{n}=5)\end{array}$ & $\begin{array}{c}\text { B } \\
(\mathbf{n}=11)\end{array}$ & $\begin{array}{c}C \\
(n=32)\end{array}$ & & \\
\hline $\begin{array}{l}\text { AFP(ng/ml) } \\
\mathrm{X} \pm \mathrm{SD} \\
\text { Range }\end{array}$ & $\begin{array}{c}1510.80 \pm 1355.54 \\
13-2750\end{array}$ & $\begin{array}{c}536.45 \pm 790.44 \\
7-2750\end{array}$ & $\begin{array}{c}737.37 \pm 988.75 \\
19-2850\end{array}$ & 0.64 & 0.72 \\
\hline \multirow[t]{3}{*}{$\begin{array}{l}\text { Gp73 (ng/l) } \\
\mathrm{X} \pm \text { SD } \\
\text { Range } \\
\end{array}$} & $\begin{array}{c}986.0 \pm 132.64 \\
895-1220\end{array}$ & $\begin{array}{c}1661.45 \pm 785.76 \\
895-3515\end{array}$ & $\begin{array}{c}1929.94 \pm 709.9 \\
815-2915\end{array}$ & 9.92 & 0.007 \\
\hline & \multicolumn{3}{|c|}{ Child-Pugh classification in GII } & & \\
\hline & $\begin{array}{c}\mathbf{A} \\
(n=3)\end{array}$ & $\begin{array}{c}B \\
(n=6)\end{array}$ & $\begin{array}{c}\mathrm{C} \\
(\mathrm{n}=11)\end{array}$ & & \\
\hline $\begin{array}{l}\text { AFP }(\mathbf{n g} / \mathbf{m l}) \\
\mathrm{X} \pm \mathrm{SD} \\
\text { Range }\end{array}$ & $\begin{array}{c}26.33 \pm 29.16 \\
9-60\end{array}$ & $\begin{array}{c}53.17 \pm 33.82 \\
13-90\end{array}$ & $\begin{array}{c}18.36 \pm 13.65 \\
1-44\end{array}$ & 3.93 & 0.14 \\
\hline $\begin{array}{l}\text { Gp73 (ng/l) } \\
\mathrm{X} \pm \text { SD } \\
\text { Range }\end{array}$ & $\begin{array}{c}703.0 \pm 96.16 \\
645-814\end{array}$ & $\begin{array}{c}776.5 \pm 44.13 \\
699-815\end{array}$ & $\begin{array}{c}789.18 \pm 75.96 \\
655-890\end{array}$ & 2.21 & 0.33 \\
\hline
\end{tabular}

\section{ROC curve of AFP and GP73 for diagnosis of HCC versus cirrhotic cases}

\section{ROC Curve}

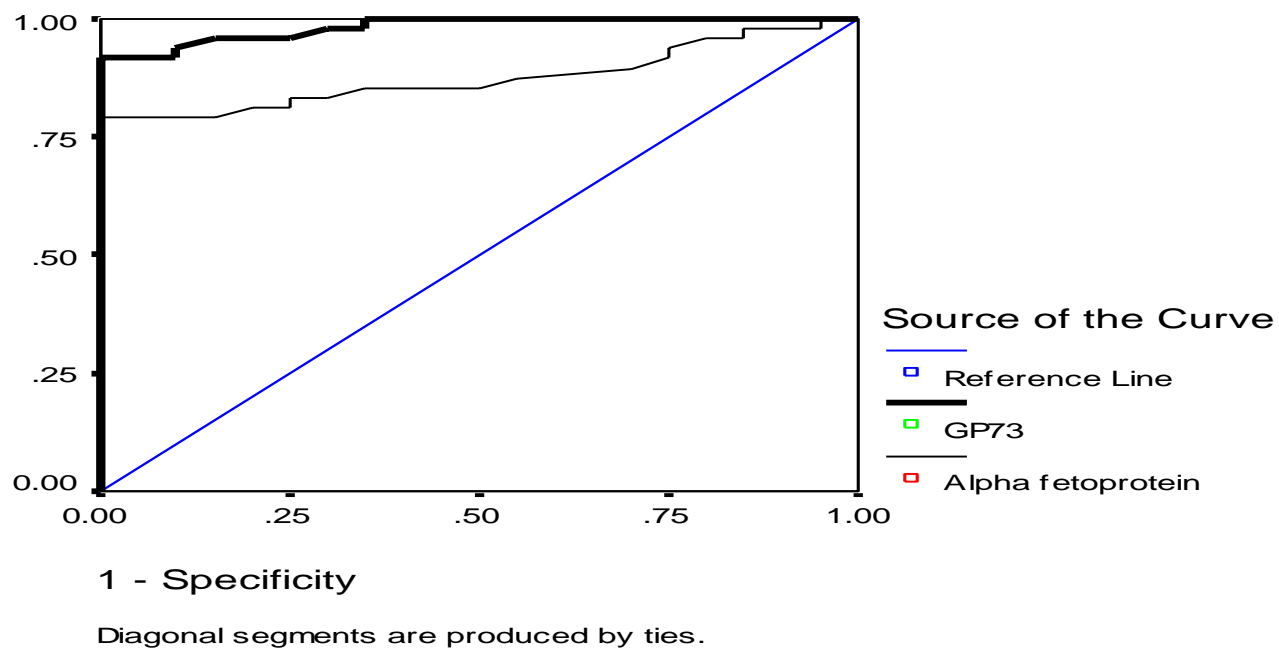

Figure (2) : ROC curve of AFP and GP73 for diagnosis of HCC versus cirrhotic cases. 
Table (6): Diagnostic performance of AFP and gp73 in diagnosis of HCC

\begin{tabular}{|l|c|c|c|}
\hline \multicolumn{1}{|c|}{ Variable } & AFP & GP73 & Both \\
\hline AUC & 0.88 & 0.98 & --- \\
\hline P Value & $<0.001$ & $<0.001$ & --- \\
\hline Cutoff & 55 & 847.5 & ---- \\
\hline Sensitivity (\%) & 81.3 & 93.8 & 95.8 \\
\hline Specificity (\%) & 70.0 & 90.0 & 70.0 \\
\hline Positive predictive value (\%) & 86.7 & 95.7 & 88.5 \\
\hline Negative predictive value (\%) & 60.9 & 85.7 & 87.5 \\
\hline Accuracy (\%) & 77.9 & 92.6 & 88.2 \\
\hline
\end{tabular}

\section{DISCUSSION}

Regarding age distribution in HCC group, the present study showed that age was ranging from 43 to 76 years with mean age of the patients 57.85 \pm 7.23 . This was in agreement with Amer et al. [8] who reported thatmean age of the patients with HCC was $54 \pm 8.6$ years, while Yang and Roberts [9] found $\mathrm{HCC}$ to be more frequent in individuals of an average age of about 64 years andEl-Serag[10] reported that HCC is rare before 40 and peaks around age 70 . The endemicity of $\mathrm{HCV}$ infection in Egypt, in addition, other contributing environmental factors such as the presence of aflatoxin in many food stuff, and contamination with insecticides may explain the occurrence of HCC at younger age groups [11].

Regarding the gender distribution, the present study showed that HCC is more prevalent in men than in women with 3.8 times higher in men, these results were in agreement with ElSerag[10] who reported that there was a striking male HCC predominance, with the highest male: female ratios (averaging between 2:1 and 4:1) in high HCC incidence areas. Male sex predominance of HCC may be attributed to sex hormones and sex-specific differences in exposure to risk factors. Men are more likely to be infected with $\mathrm{HBV}$ and $\mathrm{HCV}$, consume alcohol, smoke cigarettes, and have increased iron stores. However, experiments show a $2-8$ fold increase in HCC development in male mice. These data support the hypothesis that androgens influence HCC progression rather than sex-specific exposure to risk factors [10]. Several studies conducted in Taiwan reported a positive association between increased circulating testosterone levels and $\mathrm{HCC}$ in HBV-infected men [12].

In the present study, Chronic HCV was the commonest etiology of cirrhosis in HCC group
(85.4\%), HBV was less frequent $(8.3 \%)$ and coinfection with both viruses in $(6.3 \%)$, this was in agreement with Amer et al. [8] who found that the major risk factor for cirrhosis and the subsequent development of HCC was chronic hepatitis $\mathrm{C}(67.7 \%)$ and to a lesser extent chronic hepatitis B (8.8\%) and coinfection with both viruses $(4.8 \%)$. The major factors increasing the risk of $\mathrm{HCC}$ are chronic hepatitis $\mathrm{B}$ and $\mathrm{C}$ as well as cirrhosis, irrespective of its etiology. In North America, Europe, and other areas of low prevalence of HCC, most patients have underlying cirrhosis unrelated to HBV or HCV infection [13]. The etiological contribution of viral hepatitis toward the risk of HCC differs in different countries according to the prevalence of viral infection and other causes of liver cirrhosis. Kumar et al. [14] found that chronic HBV infection is the major factor for the development of HCC in China.

As regards the relation between HCC and the severity of cirrhosis, the present study revealed that about two thirds of HCC patients (66.7\%) were Child $\mathrm{C}$ cirrhosis, $22.9 \%$ of the patients were Child B and $10.4 \%$ were Child A liver cirrhosis). These results were in agreement with Amer et al. [8] who found that $54.65 \%$ of $\mathrm{HCC}$ patients were Child $\mathrm{C}$ cirrhosis and $\mathrm{HCC}$ occurred least frequently in patients with Child $\mathrm{A}$ liver cirrhosis (15.4\%).

The present study revealed a higher level of AFP in both cirrhotic and HCC groups than the control group and it is significantly higher in HCC group when compared to cirrhotic and control groups. AFP levels in cirrhotic group ranged from 1 to $90 \mathrm{ng} / \mathrm{ml}$ and in HCC group it was $1.9-2850 \mathrm{ng} / \mathrm{ml}$. The value of AFP in diagnosis of HCC was variable in different studies. Chan et al. [15] found elevated serum AFP levels not more than $200 \mathrm{ng} / \mathrm{ml}$ in patients with benign liver conditions such as hepatitis and 
cirrhosis. Also Yoshida et al. [16] reported normal AFP levels in approximately one-third of patients with $\mathrm{HCC}$ a large number of HCC patients have AFP values $<400 \mathrm{ng} / \mathrm{mL}$, making them very difficult to undergo detection and prognosis of HCC. Similarly, Tsai et al. [17] observed that an AFP level less than $400 \mathrm{ng} / \mathrm{ml}$ was noted in $51 \%$ of HCC patients, furthermore, at least one third of small HCC and up to $30 \%$ of advanced HCC will be missed unless other diagnostic tools are used. In addition, AFP may be elevated in nonmalignant liver diseases, so, it is obvious that AFP alone is not a reliable indicator for detection and prognosis of $\mathrm{HCC}$.

In our study, statistical analysis revealed that there was highly significant increase in mean values of serum GP73 in HCC group in comparison with other groups and in cirrhotic group in comparison with control group. GP73 in HCC group ranged $810-3515 \mathrm{ng} / \mathrm{l}$ and in cirrhotic group ranged 635-890 $\mathrm{ng} / \mathrm{l}$ while in control group it was $350-665$. These results were in agreement with Mao et al. [18] have found that the elevation of serum GP73 is mildest in chronic viral hepatitis, moderate in patients with cirrhosis and dramatic increased in patients with HCC. Similarly Tian et al. [19], El Shafie et al. [20] and Wang et al. [21] reported that, serum GP73 in HCC was higher than in liver cirrhosis and chronic hepatitis and in all patients were higher than those in healthy individuals. On the other hand Ozkan et al. [22] and Shi et al. [23] failed to find significant elevation of serum GP73 in HCC groups compared with that in liver cirrhosis groups and that the potential clinical value of GP73 as a better serum biomarker than AFP remains controversial.

The relation between elevation of serum GP73 in patients with HCC and the etiology of liver cirrhosis couldn't be assessed in the present study because of the small number of patients with etiology other than HCV (only 4 patients with HCC have chronic HBV infection), although it was found that serum GP73 was increased in HCC that developed on top of cirrhosis caused by either HCV or HBV. Previous study reported that the most profound elevation of serum levels of GP73 was detected in patients who had developed an HCC on the background of HCV infection [24]. Similarly Riener et al. [25] found significant (3- to 5-fold) increases the serum GP73 levels were seen in HCC patients with underlying $\mathrm{HCV}$ infection (especially $\mathrm{HCV}$ genotype $1 b$ ) when compared with patients with
HCC unrelated to HCV. However Mao et al. [26] showed that serum GP73 levels in HCC patients with underlying $\mathrm{HBV}$ infection were significantly higher than those of the HBV carriers, patients with liver cirrhosis, and healthy controls. They reported that serum GP73 had a higher sensitivity and specificity in diagnosis of hepatitis B-related HCC than AFP, and that it could be as an effective HCC tumor marker in Chinese Patients.

In the current study there was no significant difference in mean values of AFP as regard tumor size however $\mathrm{Ba}$ et al. [27] repotted that serum AFP levels have been shown to correlate with tumor size. There was significant increase in mean values of serum GP73 in patients with HCC with increased tumor size (more than $5 \mathrm{~cm}$ ), this was in agreement with Sun et al. [28]. In contrast,Ozkan et al. [22] and Mao et al. [18] reported that serum levels of GP73 were not correlated with tumor sizes.

In the current study there was significant increase in mean value of serum GP73 in patients with HCC complicated by portal vein thrombosis while there was no significant difference as regards mean value of AFP. These results were similar to those obtained by El Shafie et al. [20] who reported that the level of GP73 correlated with more aggressive tumor characters including vascular invasion with no significant difference as regards mean value of AFP, On the other hand Ozkan et al. [22] reported that there was no correlationbetween GP73 levelsportal

vein thrombosis. In the current study there was significant increase in mean value of serum GP73 in patients with HCC associated with lymph nodes, this was in agreement withFimmel and Wright [29] who recorded that, the degree of GP73 expression correlated with lymph nodes invasion while Ozkan et al. [22] did not find significant correlation.

The present study revealed significant increase in the mean values of GP73 in HCC group in relation to the severity of liver cirrhosis (the highest value was in patients with Child-Pugh grade $\mathrm{C}$. This was in agreement with El Shafie et al. [20] who found significant correlation between serum GP73 level and child score in HCC patients on the other hand Mao et al. [18] reported that serum levels of GP73 in patients with HCC were not correlated with Child-Pugh grades (A, B,C). our study revealed no significant difference in mean values of GP73 as regard Child-Pugh grades $(\mathrm{A}, \mathrm{B}, \mathrm{C})$ in the cirrhotic group, on the 
other hand Tian et al. [19] reported that, serum GP73 in patients with Child-Pugh class A was lower than in class $\mathrm{B}$ and $\mathrm{C}$ in liver cirrhosis.

In the current study the area under AUROC for AFP was 0.88 and at cut off point $55 \mathrm{ng} / \mathrm{ml}$, the sensitivity of AFP was $81.3 \%$ and specificity was 70.0\%. Trevisani et al. [30] reported that specificity of AFP varied from about $76 \%$ to $96 \%$ and increased with elevated cutoff value, also El Shafie et al. [20] found that AFP had a sensitivity of $77.4 \%$ and a specificity of $60 \%$ at a cut-off $28.51 \mathrm{ng} / \mathrm{ml}$.

In our study the area under AUROC for GP73 was 0.98 with sensitivity $93.8 \%$ and specificity $90.0 \%$ at cut off point $847.5 \mathrm{ng} / \mathrm{l}$. Marrero and Lok[31] postulated that, GP73 is up-regulated in HCC and measurement of serum GP73 revealed a sensitivity and specificity of $69 \%$ and $75 \%$, respectively. Also El Shafie et al. [20] postulated that GP73 had a sensitivity of $87 \%$ and a specificity of $95 \%$ at the optimal cut-off value of7.62 $\mathrm{ng} / \mathrm{ml}$. These results were disappointing with Gu et al. [32] who found that GP73 elevated in patients with liver disease but did not distinguish between HCC, cirrhosis, and chronic hepatitis. Riener et al. [25] reported GP73 was surprisingly found to be decreased in HCC patients and doubt on the diagnostic utility of GP73 as a serum marker of HCC.

In our study we found that with combined use of AFP and GP73 there was significant increase in sensitivity of detection of HCC up to $95.8 \%$ than using either of them alone, these results were in agreement with Wang et al. [33] and Mao et al. [18] who reported that the combined measurement of GP73 and AFP can further increase the sensitivity for the detection of HCC, also Omran et al. [34] reported that by combining serum GP73 and AFP for the diagnosis of HCC, it was found that sensitivity rises to $93 \%$ and El Shafie et al. [20] reported that when GP73 used in combination with AFP, they lead to an enhanced sensitivity of detection of HCC up to $90.3 \%$.

\section{CONCLUSION}

The sensitivity, accuracy and negative predictive value for diagnosis of HCC in cirrhotic patients increased to $95.8 \%, 88.2 \%$ and $87.5 \%$ respectively with combined assay of serum GP73 and serum AFP. Serum GP73 levels correlated positively with tumor size, portal vein thrombosis and lymph node involvement in cirrhotic patients with HCC.
Funding: None.

Conflicts of interest: The authors declare that there is no conflict of interest.

Ethical approval: Was granted by the Institutional Review Board and informed consent was obtained from each patient prior to inclusion in the study.

\section{REFERENCES}

1. Ferlay J, Shin HR, Bray F, Forman D, Mathers C, Parkin DM . Estimates of worldwide burden of cancer in 2008: GLOBOCAN 2008. Int $J$ Cancer2010; 127(12):2893-2917

2. Fattovich G, Stroffolini T, Zagni I, Donato F. Hepatocellular carcinoma in cirrhosis: incidence and risk factors. Gastroenterology 2004;127(Suppl1):35-50.

3. Poon D, Anderson BO, Chen LT, Tanaka K, Lau WY, Van Cutsem E et al. Epidemiology and Management of hepatocellular carcinoma in Asia: Consensus statement from the Asian Oncology Summit. Lancet Oncol 2009; 10:1111-1118.

4. Daniele B, Bencivenga A, MegnaAS , TinessaV . Alpha-fetoprotein and ultrasonography screening for hepatocellular carcinoma. Gastro-enterology 2004; 127: S108-S112.

5. Beale G, Chattopadhyay D, Gray J, Stewar S, Hudson M, Day C, et al. AFP, PIVKAII, GP3, SCCA-1 and follisatin as surveillance biomarkers for hepatocellular cancer in non-alcoholic and alcoholic fatty liver disease. BMC Cancer 2008; 8:1471-2407.

6. Kladney RD, Bulla GA, Guo L, Mason AL, Tollefson AE, Simon DJ, et al. GP73, a novel Golgi-localized protein upregulated by viral infection. Gene 2000; 249: 53-65.

7. Norton PA, Comunale MA, Krakover J, Rodemich L, Pirog N, D'Amelio A, et al . N-linked glycosylation of the liver cancer biomarker GP73. J Cell Biochem 2008; 104: 136-149.

8. Amer, Nehad A, Gemaay, Mohamed Ac, Mohamed, Azza E, et al, (2013): Prevalence of viral hepatitis in Egyptian patients with hepatocellular carcinoma. Egyptian Liver Journal 2013;3(1):6-9.

9. Yang JD, Roberts LR. Epidemiology and management of hepatocellular carcinoma. Infect Dis Clin North Am 2010; 24: 899-919.

10. El-Serag . Review Article, Current Concepts, Hepatocellular Carcinoma (HCC); N Engl J Med 2011; 365:1118-1127.

11. Abdel-Wahab M, El-Ghawalby YN, Mostafa M, Sultan A, El-Sadany M, Fathy $O$, et al. Epidemiology of hepatocellular carcinoma in lower Egypt, Mansoura Gastroenterology Center. Hepatogastroenterology 2007; 54:157-162. 
12. Yuan JM, Ross RK, Stanczyk FZ, GovindarajanS, GaoYT, Henderson BE, et al. A cohort study of serum testosterone and hepatocellular carcinoma in Shanghai, China. Int J Cancer 1995; 63: 491-3.

13. Constantin CV, Streba CT, Rogoveanu I, NitaStefanescu L, Ionescu AG. Cirrhosis and chronic viral hepatitis as risk factors for hepatocellular carcinoma: Romanian single-clinic experience. Maedica (Buchar) 2010; 5: 265-270.

14. Kumar M, Kumar R, Hissar SS, Saraswat MK, SharmaBC, Sakhuja P, et al. Risk factors analysis for hepatocellular carcinoma in patients with and without cirrhosis: a case-control study of 213 hepatocellular carcinoma patients from India. J GastroenterolHepatol 2007; 22:11041111.

15. Chan DW, Booth RA and Diamondis EP . Tumor markers. In: Textbook of Clinical Chemistry and Molecular Diagnostics. BurtisCA, Ashwood ER and Burns DE (eds.): 4th ed, Elsevier Saunders 2006; ch. (23) pp; 745-795.

16. Yoshida, S, Kurokohchi K, Arima K, Masaki T, Hosomi N, Funaki T, et al. Clinical significance of Lens culinaris agglutinin-reactive fraction of serum alpha-fetoprotein in patients with hepatocellular carcinoma. Int. J. Oncol 2002; 20, 305-309.

17. Tsai JF, Jeng JE, Chuang LY, You HL, Ho MS, Lai CS, et al. Serum insulin-like growth factor-II and alpha-fetoprotein as tumor markers of hepatocellular carcinoma. TumourBiol 2003; 24(6): 291-8.

18. Mao Y, Yang H, Xu H, Lu X, Sang X, Du S et al. (2010): Golgi protein 73 (GOLPH2) is a valuable serum marker for hepatocellular carcinoma. Gut; 59(12):1687-93

19. Tian L1, Wang Y, Xu D, Gui J, Jia X, Tong H, et al. Serological AFP/Golgi protein 73 could be a new diagnostic parameter of hepatic diseases. Int $J$ Cancer 2011; 129(8):1923-31.

20. El Shafie MA, Fawzy AM, Abd Al Monem E, Abbass S, Zakaria D, El Baz S . Golgi Protein 73 (GP73) as a Novel Serum Marker for Early Detection of Hepatocellular Carcinoma in Egyptian Patients. Life Science J 2012; 9(2):823830.

21. Wang Y, Yang H, Xu H, Lu X, Sang X, Zhong S, et al. Golgi protein 73, not Glypican-3, may be a tumor marker complementary to $\alpha$-Fetoprotein for hepatocellular carcinoma diagnosis. $J$ GastroenterolHepatol 2014; 29(3): 597-602.

22. Ozkan H, Erdal H, Tutkak H, Karaeren Z, Yakut $\mathrm{M}$, Yüksel $\mathrm{O}$, et al. Diagnostic and prognostic validity of Golgi protein 73 in hepatocellular carcinoma. Digestion 2010; 83:83-88.
23. Shi Y, Chen J, Li L, Sun Z, Zen L, Xu S et al. A study of diagnostic value of Golgi protein GP73 and its genetic assay in primary hepatic carcinoma. Technol Cancer Res Treat 2011; 10:287-294.

24. Marrero JA, Romano PR, Nikolaeva O, Steel L, Mehta A, Fimmel CJ, et al. GP73, a resident Golgi glycoprotein, is a novel serum marker forhepatocellular carcinoma. J Hepatol 2005; 43:1007-1012.

25. Riener MO, Stenner F, Liewen H, Soll C, Breitenstein S, Pestalozzi BC et al. Golgi Phosphoprotein 2 (GOLPH2) Expression in Liver Tumors and Its Value as a Serum Marker in Hepatocellular Carcinomas. Hepatology 2009; 49:1602-1609.

26. Mao YL, Yang HY, Xu HF, Sang XT, Lu X, Yang ZY, et al. Significance of Golgi glycoprotein 73, a new tumor marker in diagnosis of hepatocellular carcinoma: a primary study. Zhonghua Yi XueZaZhi 2008; 88: 948-951.

27. Ba MC, Long H, Tang YQ , Cui SZ: GP73 expression and its significance in the diagnosis of hepatocellular carcinoma: a review. Int $J$ ClinExpPathol ; 2012; 5(9):874-881.

28. Sun Y, Yang H, Mao Y, Xu H, Zhang J, Li G, et al. Increased GP73 expression in hepato-cellular carcinoma tissue correlates with tumor aggression but not survival. Journal of GastroenterolHepatol 2011; 26(7):1207-12.

29. Fimmel , Wright . Golgi Protein 73 as a Biomarker of Hepatocellular Cancer: Development of a Quantitative Serum Assay and Expression Studies in Hepatic and Extrahepatic Malignancies. Hepatology 2009; 49(50):1421-1423.:

30. Trevisani F, D'Intino PE, Morselli-Labate AM, Mazzella G, Accogli E, Caraceni P, et al: Serum alpha-fetoprotein for diagnosis of hepatocellular carcinoma (HCC) in patients with chronic liver disease: influence of HbsAg and anti-HCV status. J Hepatol, 2001; 34:570-575.

31. Marrero JA, Lok AS. Newermarkers for hepatocellular carcinoma. Gastroenterology 2004; 127(5Suppl 1):S113-119.

32. Gu Y, Chen W, Zhao Y, Chen L, Peng T. Quantitative analysis of elevated serum Golgi protein-73 expression in patients with liver diseases. Ann ClinBiochem 2009; 46:38-43.

33. Wang M, Long RE, Comunale MA, Junaidi O, Marrero J, Di Bisceglie AM et al. Novel Fucosylated Biomarkers for the Early Detection of Hepatocellular Carcinoma. Cancer Epidemiol Biomarkers Prev 2009; 18:1914-1921. 
34. Omran D, Esmat S, Sedrac H, El-Badry A, Ismail D, Rashed L . Can we use GP73 as a biomarker for the detection of hepatocellular carcinoma? Egyptian Liver Journal 2011; 1(1): 43-46.
Peer reviewers: Dr. Amal Fawzy; Assistant Professor of Clinical and Chemical Pathology, National Cancer Institute, Cairo University, Egypt.Dr.

Salem Yousef Mohamed, Department of Internal Medicine, Faculty of Medicine, Zagazig University, Egypt.Editor: Mohamed H Emara; Lecturer of Tropical Medicine, Faculty of Medicine ,Zagazig University, Egypt. 